\title{
Homogenization and Truncation Processes in Inflorescences of Cyperaceae
}

\author{
A. Bender ${ }^{1}$ - J. C. $\operatorname{Ramos}^{1,2}$ - J. C. Tivano' ${ }^{1}$. \\ A. C. Vegetti ${ }^{1,2,3}$ \\ ${ }^{1}$ Morfología Vegetal, Facultad de Ciencias Agrarias, Universidad Nacional del Litoral, Santa Fe, Argentina \\ ${ }^{2}$ CONICET, Consejo de Investigaciones Científicas y Técnicas de la República Argentina, Buenos Aires, \\ Argentina \\ ${ }^{3}$ Author for Correspondence; e-mail: avegetti@fca.unl.edu.ar
}

Published online: 29 April 2016

(C) The New York Botanical Garden 2016

\begin{abstract}
This work presents an analysis of the homogenization and truncation processes in Cyperaceae inflorescences. The truncation process is rare in Cyperaceae. There may be homogenized inflorescences but in general these inflorescences present a terminal spikelet. In the few studied cases of truncated inflorescences in Cyperaceae the truncation process may affect the terminal spikelet, only on the main axis and on the long primary branches (species of Cariceae, species of Lipocarpha and Ascolepis), or it may also affect the short branches on the main axis (some species of Kobresia; Cyperus giganteus, C. papyrus and C. prolifer) and on the primary long branches (Cyperus giganteus, $C$. papyrus and $C$. prolifer). The homogenized inflorescences can be disjunct or not disjunct. The disjunct homogenized inflorescences have a distal portion of short branches and a proximal portion of long branches, which lead in turn as short branches subunits. Meanhile non-disjunct homogenized inflorescences have only short or long branches, all with the same branching degree.
\end{abstract}

Keywords Inflorescences · Truncation · Homogenization · Cyperaceae

\section{Variations in the Structure of the Cyperaceae inflorescences}

Cyperaceae show a significant variation in the structure of their inflorescences (Haines \& Lye, 1983, Goetghebeur, 1998; Vegetti, 2003; Reutemann et al., 2012). The inflorescences in this family (Fig. 1) may consist of many spikelets arranged in a complex branching system, or a few spikelets or even a single spikelet (Haines \& Lye, 1983, Vegetti \& Tivano, 1991a; Vegetti, 1992, 1994, 2002, 2003; Heinzen \& Vegetti, 1994; Goetghebeur, 1998; Browning \& Gordon-Gray, 1999; Camelbeke, 2002; Guarise \& Vegetti, 2007; Ahumada \& Vegetti, 2009; Reutemann et al., 2009, 2012, 2014a, 2014b; Guarise et al., 2012; Lucero \& Vegetti, 2012; Lucero et al., 2014; Dellaferrera \& Vegetti, 2015).

A. Bender and J. C. Ramos are joint first authors. 
The inflorescence results from the activity of its own meristems, which defines the production or loss of iterative structures, and it is finally determined by the number, size and relative arrangement of their branches (Guarise \& Vegetti, 2007). Angiosperm inflorescence can be described by a simple and dynamic model of development (Kellogg, 2000). In this model for Cyperaceae, any meristem may have one of these three fates: it may (1) produce indeterminate lateral branches, (2) terminate in a spikelet, or (3) stop the development without forming organs. Again, each of the indeterminate meristems could choose one of these three fates, and so on (Kellogg, 2000). Thus, different inflorescence architecture may be described by the combinatorial patterns of these meristems decisions (Reinheimer et al., 2013).

Early in development, the shoot apical meristem produces only leaves, each of which develops a meristem in its axil. After receiving an endogenous (hormonal) or exogenous (light, heat) signal the meristem acquires the capacity to produce an inflorescence (Colasanti \& Coneva, 2009; Wellmer \& Riechmann, 2010). As a general model, during inflorescence development, the apical inflorescence meristem (IM) generates bracts and their axillary meristems, called branch meristems (BM), which are generally indeterminate and produce the inflorescence branches. After several branches are produced, the IM switches and generates axillary meristems that produce one spikelet (spikelet meristem, SM), which is a determinate meristem. Next, the IM may generate or not a varying number of bracts whose axillary meristems do not develop and, finally, it generates fertile leaves (glumes) with floral meristems (FM) in their axils, which make up the terminal spikelet.

In Cyperaceae the inflorescence complexity is reduced distally (e.g., paniculodium, decomposed and composed anthelodium, Reutemann et al., 2012; Fig. 1 a). In some species the number of branches and their branching degree are reduced, appearing simple anthelodium, spike of spikelets and fascicle of spikelets (Fig. 1 b-e). In other species, due to lack of development of axillary buds, the inflorescence is reduced to a single spikelet (Fig. 1f).

In Cyperaceae the IM: (1) may produce only one terminal spikelet and the inflorescence lacks branches being formed only by one spikelet; (2) may produce spikelet meristems directly on their flanks, creating a "spike-like" structure or a fascicle of spikelets; (3) or it may produce branches. In this last case, these branches may only produce spikelet meristems (in species with inflorescencences reduced to primary branches with secondary spikelets), or they may produce new branch meristems and the inflorescence producing second-, third-, or higher-order branches. Consequently, in the inflorescences of the cases 1 and 2 we recognize two only types of axillary meristems: the spikelet meristem (SM) and the floral meristem (FM). In the inflorescences of the case 3, we recognize three types of axillary meristems: the branch meristem (BM), the spikelet meristem (SM) and the flower meristem (FM). In the branched inflorescences, the fate of the inflorescence meristem is independent of that of the primary-, secondary-, and higher order branches, which may also terminate in spikelets or not (Kellogg, 2015).

As noted by Ikeda-Kawakatsu et al. (2009), the architecture of the branched inflorescence is determined by the precise developmental timing of the conversion of a branch meristem to a spikelet meristem. If the conversion happens early in development, then few higher-order meristems are produced, whereas if conversion from 

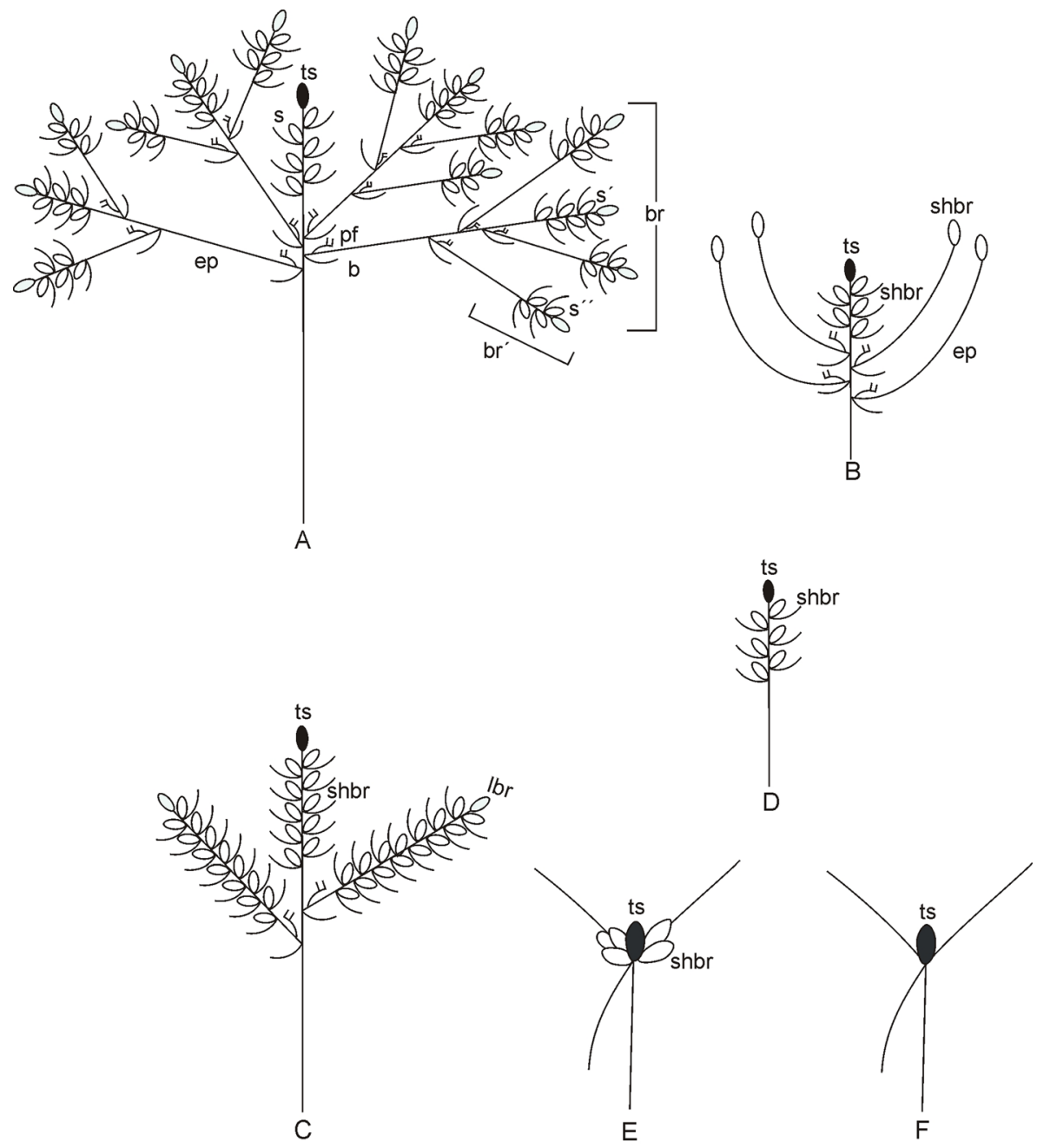

Fig. 1 Diversity of Cyperaceae inflorescences: a, Compound anthelodium; b, Simple anthelodium; c, Compound spike of spikelets; d, spike of spikelets; e, fascicle of spikelets; $\mathbf{f}$, Inflorescence constituted by only one spikelet. References: b, bract; br, primary branch; br', secondary branch; ep, epipodium; lbr, long branche; pf, prophyll; s, primary spikelet; s', secondary spikelet; s'", terciary spikelet; shbr, short branch; ts, terminal spikelet

branch meristem identity to spikelet meristem identity is delayed, then there is an opportunity for producing more branches (Kellogg, 2015).

Whether branches are produced or not is determined by the fate of the inflorescence meristem, which varies between species and genera (Kellogg 2000, 2006; Malcomber et al., 2006; Perreta et al., 2009). The complexity of the inflorescences is therefore related to the behavior of the IM that can produce branched inflorescences (Fig. 1a, c), simple anthelodium (Fig. 1b), fascicle of spikelets (Fig. 1e), spike of spikelets (Fig. 1d) or unispicate inflorescences (Fig. 1f). The complexity of inflorescences is related: (1) in the branched inflorescences, to the number and branching degree of the primary branches and to the number of primary spikelet meristems developed by the IM before 
producing the terminal spikelet; and (2) in the spike of spikelets and fascicle of spikelets, to the number of primary spikelet meristems developed by the IM before producing the terminal spikelet.

This wide diversity shown by the Cyperaceae inflorescences can be explained by the analysis of some processes that operate in different way, combined or independently. These processes and the resulting structures are mainly reductives (Guarise \& Vegetti, 2008). Among them, we can mention the homogenization and the truncation processes.

\section{The Homogenization Process}

In the Cyperaceae inflorescences the primary branches go on to branch again (Fig. 1a). And generally, there is a gradual transition in the number of spikelets in each inflorescence branch and in the branching order of the inflorescence branches. The branching degree becomes distally reduced and the branches become progressively shorter toward the apex. Therefore, the basal and median branches are branched, while the distal branches are not branched and reduced to their terminal spikelet. In these inflorescences, we recognize the terminal spikelet, a zone of primary branches reduced to the terminal spikelet and a zone of primary branched branches. These last branches generate secondary, tertiary and higher order branches.

Some inflorescences in Cyperaceae present middle and proximal primary branches with similar branching degree; all these branches bearing secondary spikelets (Fig. 1c). They are homogenized inflorescences. Above the homogenized primary branches appear a variable number of branches reduced to their terminal spikelet. This section of the main axis with primary spikelets is similar to the homogenized primary branches. In these homogenized inflorescences, a distal zone of short branches (all of the primary spikelet arranged on the main axis) and a middle and proximal zone of long branches (all of primary branches bearing secondary spikelets $=$ homogenized primary branches) are differenciated.

In order to distinguish branches of various complexity, the terms long and short paracladia (=long and short branches) were applied by Vegetti \& Tivano, 1991b as they had been previously used for Dicotyledonous families by Troll (1965) and Weberling (1989). The distinction between long and short branches should be associated with the presence of a discontinuity in the branch series along the main axis of the inflorescence (Weberling et al., 1993, 1997). These authors pointed out that the short branches must be homogeneus and must appear regularly as structural subunits of the long branches.

When short and long branches are distinguished, the inflorescence is disjunct and homogenized (Rua, 1999, Fig. 1c, Fig. 2a, b). If instead, on the main axis only primary spikelets are arranged (as in the spike of spikelets, Fig. 1d and simple anthelodium, Fig. 1b) or long branches are arranged (as in some truncated inflorescences, Fig. 2c), the homogenized inflorescence is non-disjunct. The homogenized inflorescences show disjunction (Fig. 1c, Fig. 2a, b) when an abrupt transition between the proximal portion of an inflorescence, which is provided with long branches and the distal portion, with short branches is presented (Weberling, 1989; Rua \& Weberling, 1998).

The homogenization represents a reductive process because the homogenized inflorescence has only primary branches bearing secondary spikelets (i.e. it is primary branches with reduced branching degree Fig. 1c; Fig. 2 a, b). In these homogenized 

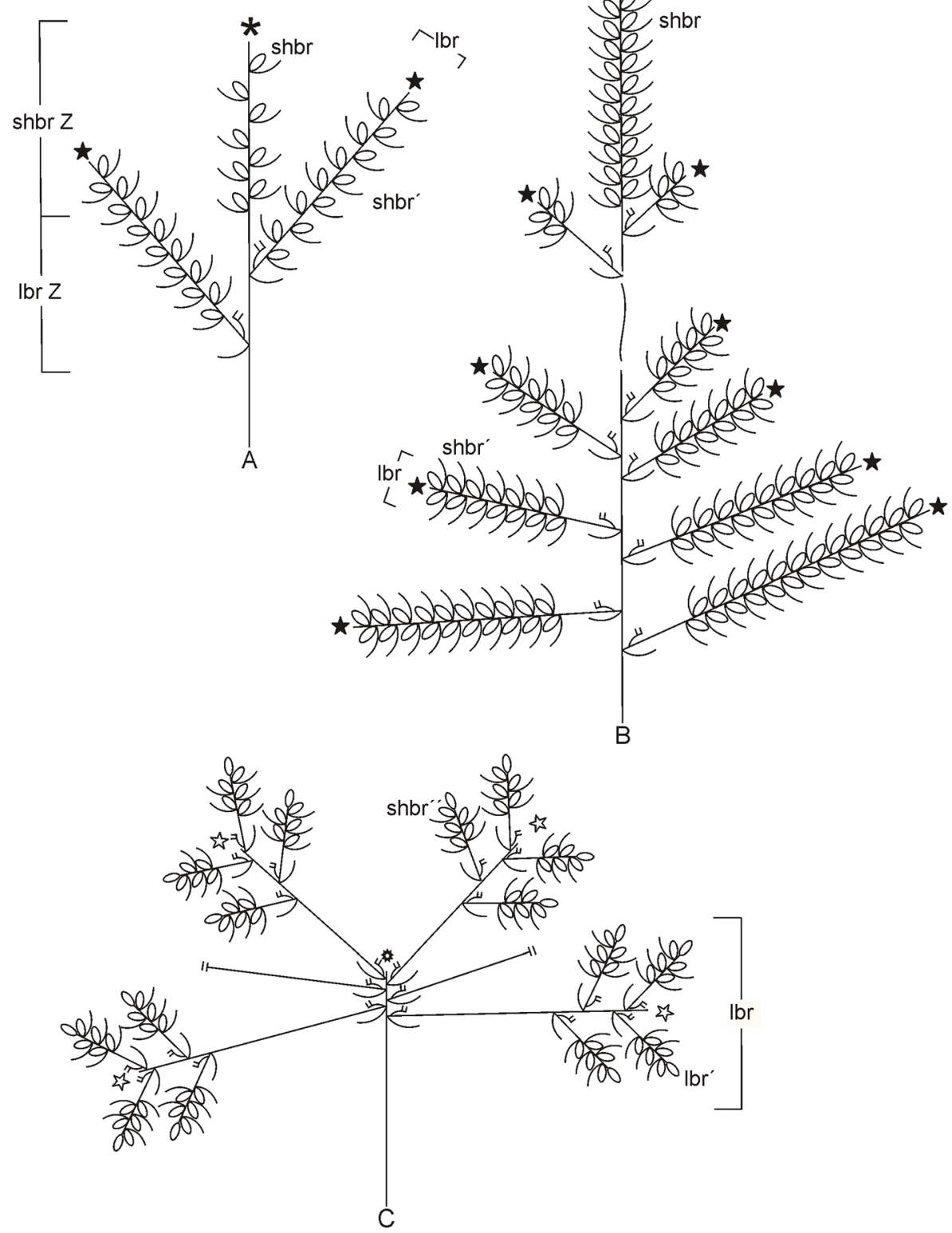

Fig. 2 Truncated Cyperaceae inflorescences: a and b, truncated spike of spikelet of Ascolepis brasiliensis (a) modified of Reutemann et al., 2014a) and Carex disticha (b) modified of Kukkonen, 1984); c, Truncated anthelodium of Cyperus giganteus. References: lbr, primary long branch; lbr', secondary long branch; lbrZ, Zone of long branches; shbr, primary short branch; shbr', secondary short branches; shbr"', terciary short branch; shbrZ, Zone of short branches; ${ }^{*}$, truncation of terminal spikelet of the main axis; $\star$, truncation of the terminal spikelet of the long branches; truncation of the terminal spikelet and zone of primary short branches of the main axis; $\$$, truncation of the terminal spikelet and secondary short branch zone of the primary long branches 
inflorescences the axillary meristems of the BMs only form SMs, which, in turn, generate branches reduced to one spikelet. After generating a certain number of primary branches with secondary branches reduced to one spikelet, the IM of the homogenized inflorescence abruptly switches to produce a certain number of branches reduced to their terminal spikelet (Fig. 1c, Fig. 2a, b). The BMs are indeterminated meristems and the SMs are determinate meristems. Indeterminate meristems make an indefinite number of organs, whereas determinate meristems are consumed after making a specific number of organs (Vollbrecht et al., 2005; Bortiri \& Hake, 2007; Kellog, 2015). The homogenization process of the inflorescence is related to the meristem determinancy (Perreta et al., 2009; Kellogg, 2015). In this sense, the meristem determinancy would guide the degree of homogenization (Salariato et al., 2010).

\section{Truncation Process}

The inflorescence truncation process was characterized by Troll (1964) and Weberling (1989). It consists of the lack of formation of the distal floral structures. This process occurs when the IM stops growing: (1) not developed the terminal spikelet (truncation of the terminal spikelet, Fig. 2a, b); (2) before forming the subzone of short branches (= primary spikelts) and the terminal spikelet (truncation of the terminal spikelet and the subzone of short branches, Fig. 2c); or (3) when only a limited number of primary long branches were formed (truncation of the terminal spikelet + subzone of short branches + some long primary branches). In grasses, these truncated inflorescences may have not developed the terminal spikelet of the long branches (Liu et al., 2007; Perreta et al., 2009).

Consequently, the truncation process may affect only the development of the terminal spikelet (Fig. 2a, b), or it may also affect, on the main axis, the development of the subzone of short branches and some long branches (Fig. 2c); and the truncation of the terminal spikelet on the long branches (Fig. 2a, b).

In Cyperaceae inflorescences, after producing a certain number of branches, the IM generally ends in a terminal spikelet forming a non truncated inflorescence (Fig. 1). This non truncated inflorescence can be homogenized (Fig. 1c, d, e) or non homogenized (Fig. 1a). Although truncation is not frequent in this family, a few species show truncated inflorescences. There are reports of truncated inflorescences in two derived tribes of the subfamily Cyperoideae: in the Cariceae tribe (Vegetti, 2002; Reutemann et al., 2012) and in the Cypereae tribe (Reutemann et al., 2014a).

The inflorescence of the Cariceae (Fig. 2b) lacks a terminal spikelet. It is a truncated inflorescence consisting of a region of homogenized distal short branches ("pseudospikelet") and a variable number of long branches. The latter have no terminal spikelet (truncated long branches) and are composed of a variable number of homogenized secondary short branches. In some species, the inflorescence present truncation of the terminal spikelet and truncation of the homogenized distal short branches. Consequently, it consists only of long branches, as described by Kobresia macrolepis Meinsh and K. pygmaea (C.B.Clarke) C.B.Clarke (Kukkonen, 1990; Vegetti, 2002).

The main characters of the inflorescences of Cariceae are related with the following reductive processes: (1) a reduction in the development of spikelets, resulting in a single flower or a few flowered spikelet; (2) a homogenization of short branches on the main axis and on long branches and 3 ) the truncation of the terminal spikelet on the 
main axis and on the long branches and in some species the truncation of the homogenized short branches (Vegetti, 2002).

In the Cypereae tribe, the truncation has been described in some species of Cyperus L. (Perreta \& Vegetti, 2002; Vegetti, 2003), Lipocarpha R.Br. and Ascolepis Nees ex Steud. (Reutemann et al., 2014a). In Cyperus giganteus Vahl the inflorescence is truncated (Fig. 2c). The truncation in this species affects the terminal spikelet and the subzone of short branches on the main axis and on the long primary branches (Perreta \& Vegetti, 2002). Consequently, the inflorescence consist of one anthelodium with a variable number of long primary branches and long secondary branches with the epipodim developed (Fig. 2c). A similar situation occurs in Cyperus papyrus L. (Mora Osejo, 1960; Raynal, 1971; Haines \& Lye, 1983) and Cyperus prolifer LAM. (Raynal, 1971; Haines \& Lye, 1983). It is interesting to point out that even though in C. giganteus, C. papyrus and C. prolifer reduction of distal parts on the main axis and on long primary paracladia have occurred, the inflorescence is richly branched (Perreta $\&$ Vegetti, 2002). At the same time, in the inflorescence of Cyperus papyrus, the ramification is even more intense for the collateral buds development, generating a fascicle of long branches (Mora Osejo, 1960; Raynal, 1971). These collateral buds are not present in the other two species.

In Lipocarpha humboldtiana Nees and Ascolepis brasiliensis (Kunth) Benth. ex C.B.Clarke the truncation process affects only the terminal spikelet of the main axis and of the long branches (Fig. 2a). These species have inflorescences formed by one spike of spikelets or by a terminal spike and a reduced number of lateral spikes (Goetghebeur, 1998; Reutemann et al., 2014a). Both, the terminal spike and the lateral spikes, lacking the terminal spikelet, their are truncated (Fig. 2a).

In some families, such as grasses, truncation is a very common process which is frequently associated with homogenization (Vegetti, 1991; Vegetti \& Anton, 2000; Reinheimer \& Vegetti, 2008; Perreta et al., 2009), and both processes account for much of the diversity among grass inflorescences (Reinheimer \& Vegetti, 2008; Perreta et al., 2009). However, while most inflorescences show varying degrees of homogenization in Cyperaceae, truncation is not common in this family. In those few species of Cyperaceae, where truncation does occurs, inflorescences are homogenized (Fig. 2). A similar situation has been reported for grasses in which all truncated inflorescences are homogenized. About this, Weberling et al. (1993) considers that the truncation of the terminal spikelet is generally synchronized with the homogenization of the distal portion of the main axis.

The developmental genetics has been extensively studied in grasses (Kellogg, 2000, 2006, 2007, 2015; Bommert et al., 2005; Vollbrecht et al., 2005; Malcomber et al., 2006; Bortiri \& Hake, 2007; Skirpan et al., 2008; Huang et al., 2009; McSteen, 2009; Piao et al., 2009; Thompson and Hake, 2009; Terao et al., 2009; Gao et al., 2010; Kobayashi et al., 2010, 2012; Li et al., 2011). In Cyperaceae there is little research on developmental genetics (Prychid \& Bruhl. 2013).

\section{Conclusions}

The truncation process is rare in Cyperaceae. There may be homogenized inflorescences, but in general these inflorescences present at terminal spikelet (Fig. 1c-e). In the 
few studied cases of truncated inflorescences in Cyperaceae, the truncation process may affect only the terminal spikelet on the main axis and on long primary branches (species of Cariceae, species of Lipocarpha and Ascolepis, Fig. 2a, b), or it may also affect the short branches on the main axis (some species of Kobresia; Cyperus giganteus, C. papyrus and $C$. prolifer, Fig. 2c) and on the primary long branches (Cyperus giganteus, C. papyrus and C. prolifer, Fig. 2c). Within Cyperaceae, homogenized inflorescences can be recognized disjunct (Fig. 1b, c, Fig. 2a, b) and non disjunct (Fig. 1d, Fig. 2c).

To establish a suite of characters to satisfactorily deal with general inflorescence form, we recommend to pay special attention in: (1) homogenization degree; (2) characteristics of the subzone of short and long branches (in homogenized inflorescences); (3) presence or absence of the terminal spikelet of the main axis; (2) presence or absence of the short branche subzone on the main axis; (3) presence or absence of the terminal spikelet on the primary long branches; (4) presence or absence of the short branche subzone on the primary long branches.

In studies of the evolution of morphological diversity of the Cyperaceae inflorescences in large clades, the combination of developmental and mature structure studies is essential. This will contribute to a more detailed interpretation of the family's different genera inflorescences as well as to a description of a larger morphological variability. Such studies will contribute to establish new characters that may be useful in future taxonomic and philogenetic analyses. In addition to the combination of morphological and developmental structural studies, the realization of development genetics studies would be important in Cyperaceae, by analyzing the genes that determine the homogenization and truncation processes in the family.

\section{Literature Cited}

Ahumada, O. \& A. C. Vegetti. 2009. Inflorescence structure in species of Scleria subgenus Hypoporum and subgenus Scleria (Sclerieae-Cyperaceae). Plant Systematic and Evolution 281: 115-135.

Bommert, P., N. Satoh-Nagasawa, D. Jackson \& H. Y. Hirano. 2005. Genetics and evolution of grass inflorescence and flower development. Plant Cell Physiology 46: 69-78.

Bortiri, E. \& S. Hake. 2007. Flowering and determinacy in maize. Journal of Experimental Botany 58: 909916.

Browning, J. \& K. D. Gordon-Gray. 1999. The inflorescence in southern African species of Bolboschoenus (Cyperaceae). Annales Botanici Fennici 36: 81-97.

Camelbeke, K. 2002. Morphology and taxonomy of genus Scleria (Cyperaceae) in Tropical South America. Tesis Doctoral. Gent. Belgium.

Colasanti, J., \& V. Coneva. 2009. Mechanisms of floral induction in grasses: something borrowed, something new. Plant Physiology 149: 56-62.

Dellaferrera, I. \& A. C. Vegetti. 2015 Inflorescence structure and its relationship with Sclerieae, Bisboeckelereae, Cryptagieae and Trilepideae tribes (Cyperoideae-Cyperaceae). Bot. Rev. 81 (2): 179188.

Gao, X., W. Liang, C. Yin, S. Ji, H. Wang, X. Su, C. Guo, H. Kong, H. Xue \& D. Zhang. 2010. The SEPALLATAlike gene OsMADS34 is required for rice inflorescence and spikelet development. Plant Physiology 153:728-740.

Goetghebeur, P. 1998. Cyperaceae. In: Kubitzki, K., H. Huber, P. J. Rusall, P. S. Stevens \& T. Stüzel (eds.). The families and genera of plants, 4: 141-190. Springer Verlag, Berlin.

Guarise, N. \& A. C. Vegetti. 2007. The Inflorescences structure of Cyperus L. section Luzuloidei Kunth (Cyperaceae). Plant Systematic and Evolution 271: 41-63. 
\& A. C. Vegetti. 2008. Processes responsible of the structural diversity of the Cyperaceae inflorescence: hypothetical evolutionary trends. Flora 203 (8): 640-647.

$\longrightarrow$ - $\longrightarrow$ R R. Pozner. 2012. Multiple origin of congested inflorescences in Cyperus s.s.: developmental and structural evidence. American Journal of Botany 99: 1276-1288.

Haines, R. W. \& K. A. Lye. 1983. The sedges and rushes of East Africa. East African Nat. Hist. Soc. Nairobi.

Heinzen, F. \& A. C. Vegetti. 1994. Typoloy of the Inflorescence in Cyperus corymbosus var. subnodosus and C. rotundus. Beitrage Biologie der Pflanzen 68: 263-273.

Huang, X., Q. Qian, Z. Liu, H. Sun, S. He, D. Luo, G. Xia, C. Chu, J. Li \& X. Fu. 2009. Natural variation at the DEP1 locus enhances grain yield in rice. Nature Genetics 41: 494-497.

Ikeda-Kawakatsu, K., N. Yasuno, T. Oikawa, S. Iida, Y. Nagato, M. Maekawa \& J. Kyozuka. 2009. Expression level of ABERRANT PANICLE ORGANIZATION1 determines rice inflorescence form through control of cell proliferation in the meristem. Plant Physiology 150: 736-747.

Kellogg, E.A. 2000. A model of inflorescence development. In: Wilson, K.L., Morrison, D.A. (eds.) Monocots: systematics and evolution. Melbourne, Australia: CSIRO. pp. 84-88

- 2006. Beyond taxonomy: prospects for understanding morphological diversity in thegrasses (Poaceae). Darwiniana 44: 7-17.

- 2007. Floral displays: genetic control of grass inflorescences. Current Opinion in Plant Biology 10: 26-31.

- 2015. Flowering Plants. Monocots: Poaceae. In: The families and genera of vascular plants (Ed.: Kubitzki, K.), Springer. p. 1-416.

Kobayashi, K., M. Maekawa, A. Miyao, H. Hirochika \& J. Kyozuka, J. 2010. PANICLE PHYTOMER2 (PAP2), encoding a SEPALLATA subfamily MADS-box protein, positively controls spikelet meristem identity in rice. Plant Cell Physiology 51: 47-57.

—, N. Yasuno, Y. Sato, M. Yoda, R. Yamazaki, M. Kimizu, H. Yoshida, Y. Nagamura \& J. Kyozuka. 2012. Inflorescence meristem identity in rice is specified by overlapping functions of three AP1/FUL-like MADS box genes and PAP2, a SEPALLATA MADS box gene. Plant Cell 24: 1848-1859.

Kukkonen, I. 1984. On the inflorescence structure in the family Cyperaceae. Annales Botanici Fennici 21: 257-264.

- 1990. The inflorescence structure of Kobresia myosuroides and related speciesof sect. Elyna (Cyperaceae). Annales Botanici Fennici 27: 159-167.

Li, M., D. Tang, K. Wang, X. Wu, L. Lu, H. Yu, M. Gu, C. Yan \& Z. Cheng. 2011. Mutations in the F-box gene LARGER PANICLE improve the panicle architecture and enhance the grain yield in rice. Plant Biotechnology Journal 9: 1002-1013.

Liu, Q., P. M. Peterson, J. T. Columbus, N. Zhao, G. Hao \& D. Zhang. 2007. Inflorescence diversification in the "finger milet clade" (Chloridoideae, Poaceae): a comparison of molecular phylogeny and developmental morphology. American Journal of Botany 94: 1230-1247.

Lucero, L. E. \& A. C. Vegetti. 2012. Inflorescence structure in Rhynchospora Vahl (Cyperaceae). Flora 207: 47-56.

$\longrightarrow$ \& R. Reinheimer. 2014. Evolution and development of the spikelet and flower of Rhynchospora (Cyperaceae). International Journal of Plant Science 175: 186-201.

Malcomber, S.T., J. C. Preston, R. Reinheimer, J. Kossuth \& E. A. Kellogg. 2006. Developmental gene evolution and the origin of grass inflorescence diversity. Advances in Botanical Research 44: 425-481.

McSteen, P. 2009. Hormonal Regulation of Branching in Grasses. Plant Physiology 149: 46-55.

Mora Osejo, L. E. 1960. Beitrage zur Entwicklungsgeschichte und vergleichenden Morphologie der Cyperaceen. Beitrage Biologie der Pflanzen 35: 293-341.

Perreta, M. \& A. C. Vegetti. 2002. The inflorescence of Cyperus giganteus Vahl (Cyperaceae). Feddes Repertorium 113 (3-4): 256-260.

— J. C. Ramos \& A. C. Vegetti. 2009. Development and structure of the grass inflorescence. Botanical Review 75: 377-396.

Piao, R., W. Jiang, T-H. Ham, M. S. Choi, Y. Qiao, S-H. Chu, J-H. Park, M-O. Woo, Z. Jin, G. An, Lee, J. \& H-J. Koh. 2009. Map-based cloning of the ERECT PANICLE3 gene in rice. Theoretical and Applied Genetics 119: 1497-1506.

Prychid, C. J. \& J. J. Bruhl. 2013. Floral ontogeny and gene protein localization rules out euanthial interpretation of reproductive units in Lepironia (Cyperaceae, Mapanioideae, Chrysitricheae). Annals of Botany 112: 161-177.

Raynal, A. 1971. Quelques notes morphologiques sur les Cypéracées. Mitteilungen der Botanischen Staatssammlung München 10: 589-603.

Reinheimer, R. \& A. C. Vegetti. 2008. Inflorescence diversity and evolution in the PCK clade (Poaceae: Panicoideae: Paniceae). Plant Systematics and Evolution 275: 133-167. 
A. Amsler \& A. C. Vegetti. 2013. Insights into panicoid inflorescence evolution. Organisms Diversity and Evolution 13:97-110

Reutemann, A. G., N. J. Guarise, M. G. López \& A. C. Vegetti. 2009. Structure of inflorescences of selected South American species of Abildgaardia Vahl, Bulbostylis Kunth and Fimbristylis Vahl (Abildgaardieae-Cyperoideae-Cyperaceae). Plant Systematic and Evolution 283: 93-110.

— L. E. Lucero, N. J. Guarise \& A. C. Vegetti. 2012. Structure of the Cyperaceae Inflorescence. Botanical Review 78: 184-204.

—, V. Pilatti, N. J. Guarise \& A. C. Vegetti. 2014a. Typical cyperoid reproductive structures in Lipocarpha humboldtiana and Ascolepis brasiliensis (Cypereae-Cyperoideae-Cyperaceae): new evidence from a development perspective. Flora 209: 15-22.

— A. C. Vegetti \& R. Pozner. 2014b. Inflorescence Development in Abildgaardia, Bulbostylis and Fimbristylis (Cyperaceae: Cyperoideae: Abildgaardieae). Flora 210: 3-12.

Rua, G. H. 1999. Inflorescencias, Bases Teóricas para su análisis. Sociedad Argentina de Botánica. Buenos Aires.

\& F. Weberling. 1998. Grouth form and inflorescence structure of Paspalum (Poaceae-Paniceae): A comparative morphological approach. Beitrage Biologie der Pflanzen 69: 363-431.

Salariato, D., F. Zuloaga, L. Giussani \& O. Morrone. 2010. Molecular phylogeny of the subtribe Melinidinae (Poaceae: Panicoideae: Paniceae) and evolutionary trends in the homogenization of inflorescences. Molecular Phylogenetics and Evolution 56: 355-369.

Skirpan, A., X. Wu \& P. McSteen. 2008. Genetic and physical interaction suggest that BARREN STALK1 is a target of BARREN INFLORESCENCE2 in maize inflorescence development. Plant Journal 55: $787-$ 797.

Terao, T., K. Nagata, K. Morino \& T. Hirose. 2009. A gene controlling the number of primary rachis branches also controls the vascular bundle formation and hence is responsible to increase the harvest index and grain yield of rice. Theoretical and Applied Genetics 120: 875-893.

Thompson, B.E. \& S. Hake. 2009. Translational biology: from Arabidopsis flowers to grass inflorescence architecture. Plant Physiology 149: 38-45.

Troll, W. 1964. Die Infloreszenzen, Typologie und Stellung im Aufbau des Vegetationsk€orpers. I. Jena: Gustav Fischer.

- 1965. Botanischer Teil, in: Kommission für biologische Forschung, Bericht Jb. 1964. Akad. Wiss. Abh. Math. Naturwiss. K1. (Mainz): 93-111.

Vegetti, A.C. 1991. Sobre politelia en las inflorescencias de Poaceae. Kurtziana 21: 275-278.

- 1992. Tipology of the Inflorescence in species of Schoenoplectus (Cyperaceae) of Austral America. Beitrage Biologie der Pfanzen 67: 241-249.

- 1994. Typology of the Inflorescence in Species of Isolepis. Beitrage Biologie der Pflanzen 68: 21-26. . 2002. Typological reinterpretation of the inflorescences in Cariceae (Cyperaceae). Phyton 42 : 159168.

2003. Synflorescence typology in Cyperaceae. Annales Botanici Fennici 40: 35-46.

\& A. Anton. 2000. The grass inflorescence. Pp 29-31. In: S. Jacobs, \& J. Everet (eds.). Grasses, systematics and evolution. Csiro, Sidney.

\& J. C. Tivano. 1991a. Typology of sinflorescence in Schoenoplectus californicus (Cyperaceae). Beitrage Biologie der Pflanzen 66: 323-345.

\& J. C. Tivano. 1991b. Sinflorescence in Schizachyrium microstachyum (Poaceae). Beiträge zur Biologie der Pflanzen 66: 165-178.

Vollbrecht, E., P. S. Springer, L. Goh, E. S. Buckler \& R. Martienssen. 2005. Architecture of floral branch systems in maize and related grasses. Nature 436: 1119-1126.

Weberling, F. 1989. Morphology of flowers and inflorescences. Cambridge: Cambridge University Press.

, Müller-Doblies U, Müller-Doblies D. 1993. Zur deskriptiven und vergleichend- morphologischen Terminologie komplexer Infloreszenzen. Beitrage Biologie der Pflanzen 67:453-473.

— , U. Müller-Doblies, D. Müller-Doblies \& G. H. Rua. 1997. Hacia una terminología descriptiva y morfolígico-comparativa para inflorescencias complejas. Boletín de la Sociedad Argentina de Botánica 32: $171-184$.

Wellmer, F. \& J. L. Riechmann. 2010. Gene networks controlling the initiation of flower development. Trends Genetics 26: 519-527. 